\title{
The Liquid Ammonia Tanker Road Transport Safety Management Based on Fault-Tree-Analysis Method
}

\author{
Hui-dan LIN ${ }^{l, a}$, Geng-jun $\mathrm{GAO}^{2, b}$
}

1 School of Economy \& Management, Shanghai Polytechnic University, Shanghai, 201209, China;

2 Logistics Research Center, Shanghai Maritime University, Shanghai, 200135, China;

ahdlin@sspu.edu.cn, b ggj_seu@163.com

Key words: road transport; fault tree; liquid ammonia tanker; safety management; construction importance

\begin{abstract}
This article first analyzes the liquid ammonia road transport, and then uses the accident tree analysis method on liquid ammonia tanker road transportation accidents to uncover the causes of transportation accidents layer by layer. After adopting the method of minimum cut sets, the paper finds out the main causes of the accidents and puts forward the corresponding countermeasures.
\end{abstract}

\section{Introduction}

Hazardous chemical substances have diverse forms and a variety of packaging, such as $0.1 \mathrm{ml}$ of small package, 220 kilograms of barrel, 40 tons of tanker, and thousands of tons of ship, whose transportation involves people, the environment, and various factors, such as cars and management, which determines the risk coefficient much larger than other goods' transportation. Furthermore, as for itself, such as inflammable, explosive, toxic and radioactive features, the transportation of hazardous chemical substances could easily cause personal injury, property damage and environmental pollution, etc.

Of all the hazardous chemical substances' transportation of China, road transport accounts for 50\% of the whole for logistics transportation. According to statistics, there are about 240 million tons, more than 3500 varieties, including liquid ammonia volume of 3 million tons of Chinese dangerous chemicals' road transportation every year. In order to facilitate the transportation and storage of ammonia, we usually transform it into liquid ammonia. Liquid ammonia has extensive application in the industry, and it has the corrosive and volatile feature, which would easily cause to an accident in the process of transportation and storage. In the process of liquid ammonia transport, transportation accidents cannot be counted for the cause of transportation vehicle rollover, transportation equipment fire, truck leakage, rear-end collision, such as the 2015 An-Ning City' old Shi An road section K36 liquid ammonia tank car rolled over, 2014 high-speed tunnel of 21 tonnes of liquid ammonia tank car caught fire accident, the 2012 Qingdao-Yinchuan highway Xingtai Nangongshan liquid ammonia tank car overturned the disclosure, in 2015, Chongqing Lianjiang high-speed liquid ammonia tank rear-end collision, etc. These accidents will not only threat people's life and property loss, but also will pollute the environment and cause traffic inconvenience. The study of road transport safety management is not only beneficial to people vigilant, prevent the happening of the accident, reduce accident harm to people and the environment, furthermore it can also improve the efficiency and guarantee safety of road transport. 


\section{Features and Risks of Liquid Ammonia Transportation}

Liquid ammonia is formed by gaseous ammonia compression or cooling, which is a colorless liquid with irritating smell. The ammonia solubility in the water, ethanol and methanol is different. NH3 is liquid ammonia chemical formula, soluble in chloroform, ether and is a good solvent. Alkaline after ammonia soluble in water, there are two kinds of ions in solution. Among nine categories of hazardous chemical substances the liquid ammonia is a kind of 2.3 poisonous gas, with cylinders or tank filling, the weight of $0.52 \mathrm{~kg} / \mathrm{L}$ is the allowed filling ratio, liquid ammonia cylinder and tank lorry must conform to the provisions of the shipment, transit to avoid heat, the fireworks, the cylinder for a safety helmet, bottle rubber band or straw rope to prevent the intense impact and vibration. The modes of transportation of liquid ammonia are road tanker transport, railway transport truck, water tank, vessel and bottles of transport, including mainly road transport, rail transport times, less the remaining two. Road transportation of liquid ammonia is more than 3 million tons in China each year.

Liquid ammonia could erosion corrosion some plastic products; Ammonia and air mixture reaches a certain concentration range of flame combustion and explosion, such as the presence of oil or other combustible material, which leads high risk; Alkaline corrosion and stimulation for mucous membrane and skin, when it dissolves it can cause tissue necrosis. Furthermore, high concentrations can cause reflective stop breathing and cardiac arrest, people who contacts with 553 $\mathrm{mg} / \mathrm{m}^{\wedge} 3$ can lead a powerful stimulus symptom, which can bear 85 seconds. When concentrations reach $3500 \sim 7000 \mathrm{mg} / \mathrm{m}^{\wedge} 3$, it may cause instant death. The above features increase the risks in transport of the liquid ammonia.

\section{Road Transport Safety Management Based on FTA}

\section{The Accident Tree}

Fault tree (FTA) is a direction tree with a kind of description of accident causation. It may occur in system or have accident (referred to as the top event) as starting point, analysis the cause of the accident event one by one according to the causal logic relations with a tree diagram to constitute a logical model. And then the method calculates happening probability of various possible ways and events in qualitative or quantitative analysis, which selects the best security countermeasures in all the various solutions to avoid accidents. Accident tree method is intuitive and clear with very strong logicality. It can seal all kinds of system of risk evaluation, which can identify both qualitative analysis and quantitative analysis.

\section{Case Introduction}

This article selects the nearly 10 years' road transportation accidents of the liquid ammonia tanker which are shown in table 3-1. Although the select event is less, but representative. 
Table 3-1 Ammonia Tank Car Road Transportation Accidents

\begin{tabular}{|c|c|}
\hline Time & Accident \\
\hline 2016 & $\begin{array}{l}\text { Jade kay shanghai-kunming high-speed period of liquid ammonia tank car spontaneous } \\
\text { combustion at a high speed }\end{array}$ \\
\hline 2015 & Chongqing lianjiang period of liquid ammonia tank trucks piled up at a high speed \\
\hline 2015 & $\begin{array}{l}\text { The xi 'an around sweet king interchange near the liquid ammonia transport tanker } \\
\text { overturned }\end{array}$ \\
\hline 2015 & Guiyang anshun liquid ammonia tank car crashed into houses on the side of the road \\
\hline 2015 & Anning city old Shi An road section K36 liquid ammonia tank car rolled over \\
\hline 2014 & Wuhan hanshi high-speed 20 tonnes of liquid ammonia tank car spontaneous combustion \\
\hline 2014 & $\begin{array}{l}\text { Chuhe new high-speed fuyang segment was rear-ended } 24 \text { tonnes of liquid ammonia } \\
\text { tank trucks }\end{array}$ \\
\hline 2014 & $\begin{array}{l}\text { G85 chongqing highway in zhaotong direction in the cold water creek tunnel liquid } \\
\text { ammonia tank car spontaneous combustion }\end{array}$ \\
\hline 2013 & Anhui highway 206 a liquid ammonia transport vehicle collision out the road \\
\hline 2013 & Anhui fuyang region milli city the liquid ammonia tank explosion in transit \\
\hline 2013 & $\begin{array}{l}\text { Guiyang city mansion rong section of the liquid ammonia tank car side all at a high } \\
\text { speed }\end{array}$ \\
\hline 2012 & Qingdao-yinchuan highway xingtai nangongshan liquid ammonia tank car side leakage \\
\hline 2012 & Jiangxi native shanghai-kunming high-speed liquid ammonia transport vehicle rollover \\
\hline 2012 & $\begin{array}{l}\text { Jingha highway suizhong } \mathrm{m} \text { roads } 322 \text { kilometers to the liquid ammonia tank car } \\
\text { spontaneous combustion }\end{array}$ \\
\hline 2012 & $\begin{array}{l}\text { Shanghai-kunming highway says ha tae-keung county new village bridge liquid } \\
\text { ammonia tank lorry overturned }\end{array}$ \\
\hline 2011 & Chongqing fuling too large $\mathrm{b}$ avenue leaked liquid ammonia tank trucks \\
\hline 2011 & Yu qian highway liquid ammonia tank car tracing cauda \\
\hline 2010 & $\begin{array}{l}\text { Chongqing chongqing highway fu sheng to los till pigs carrying trucks and liquid } \\
\text { ammonia tank car tracing cauda }\end{array}$ \\
\hline 2009 & $\begin{array}{l}\text { Changchun road along a highway side tumbling carrying } 33 \text { tons of liquid ammonia tank } \\
\text { leakage }\end{array}$ \\
\hline 2009 & "September 6" long shen highway changchun section of liquid ammonia leakage \\
\hline 2009 & $\begin{array}{l}\text { The highway-ring around guiyang original sharp slope side near the toll road } 15 \text { tonnes } \\
\text { of liquid ammonia tank }\end{array}$ \\
\hline 2007 & Anhui tongling copper officer avenue near the liquid ammonia tank leakage \\
\hline 2007 & $\begin{array}{l}\text { Yueyang city cloud creek area, } 107 \text { national highway a incline liquid ammonia tank } \\
\text { leakage }\end{array}$ \\
\hline 2007 & Chongqing chongqing highway side of poisonous liquid ammonia tank car \\
\hline 2007 & Guizhou 302 state road side of the liquid ammonia tank leakage \\
\hline 2006 & $\begin{array}{l}\text { At the entrance of east sichuan nanchong into south high speed liquid ammonia tank car } \\
\text { rolled over }\end{array}$ \\
\hline
\end{tabular}

In the above table, the 10-year period from 2006 to 2016, there are four cases of the liquid ammonia tank car rear-end collision accident in the road transport, the four cases of spontaneous combustion, 11 cases of cartwheel, three cases of rollover leakage, including two cases of collision with other objects, 1case of exploding example, 7 cases of leakage, including three cases of cartwheel. Combined in the table together, liquid ammonia tank car road transportation accident can 
be divided into bums, rollover, leakage and impact crash.

\section{The Accident Analysis}

\section{Built Fault Tree}

According to the information of table 3-1, using fault tree analysis method, this paper takes the "liquid ammonia tank car transport accidents" as the top event $\mathrm{T}$, leakage, explosion, impact collision, side turn as intermediate events, and then we draw the fault tree, as shown in figure 3-5. Solve for Minimum Cut Sets

Cut set is a collection of basic events in the fault tree, when these basic event occurred, the top event must have happened, if in a cut any removal of a basic events will no longer be cut, the cut set is called the minimum cut sets, which lead to the top of the minimum combination of basic event.

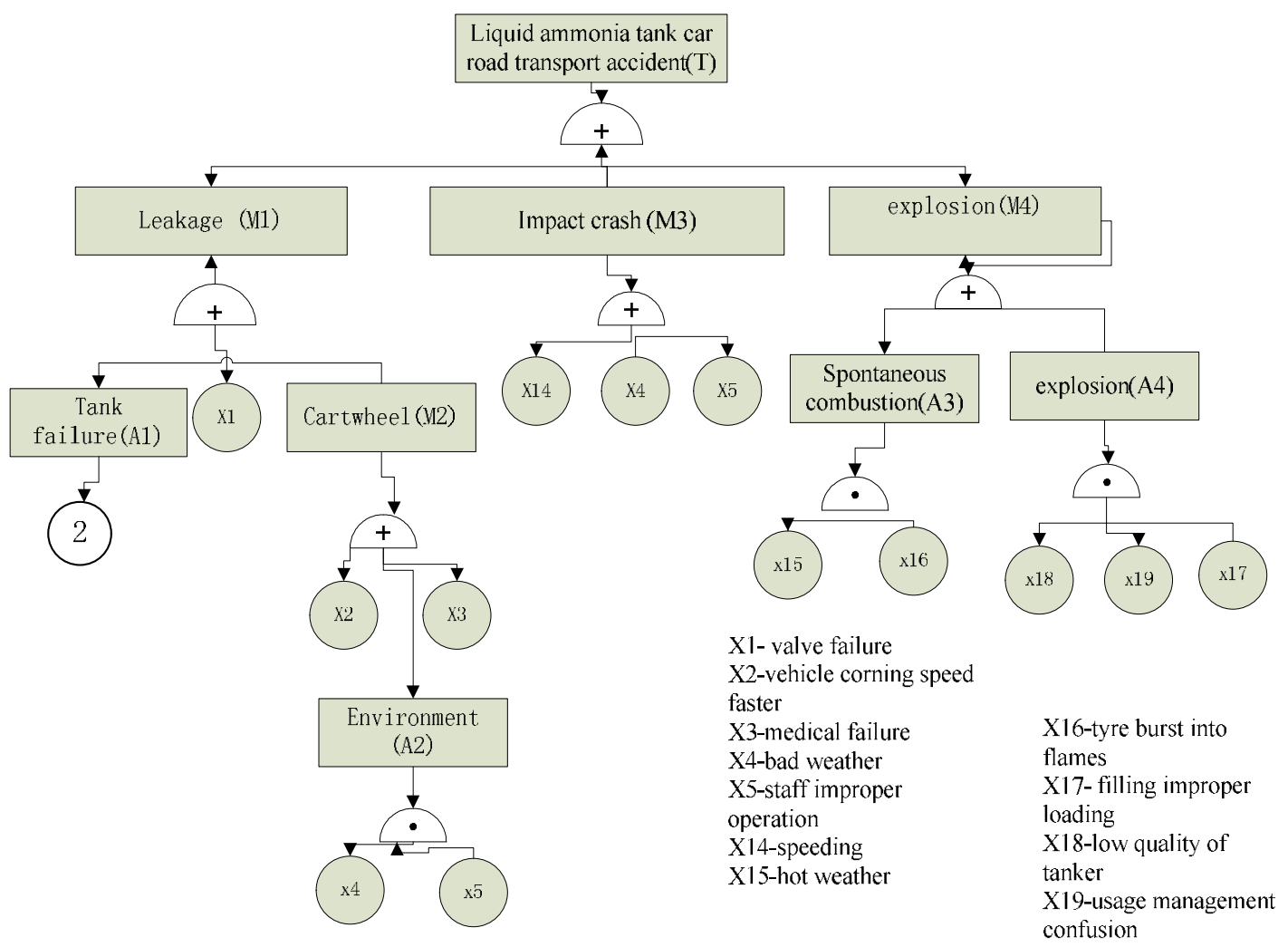

Figure 3-1 liquid ammonia tank car road transportation accident tree diagram A

Accident of minimum cut set is as follows:

$$
\begin{aligned}
\mathrm{T} & =\mathrm{M}_{1}+\mathrm{M}_{2}+\mathrm{M}_{3}+\mathrm{M}_{4} \\
& =\left(\mathrm{X}_{1}+\mathrm{A}_{1}\right)+\left(\mathrm{X}_{2}+\mathrm{X}_{3}+\mathrm{A}_{2}\right)+\left(\mathrm{X}_{4}+\mathrm{X}_{5}+\mathrm{X}_{14}\right)+\left(\mathrm{A}_{3}+\mathrm{A}_{4}\right) \\
& =\left(\mathrm{X}_{1}+\mathrm{B}_{1}+\mathrm{B}_{2}+\mathrm{B}_{3}\right)+\left(\mathrm{X}_{2}+\mathrm{X}_{3}+\mathrm{X}_{4} \cdot \mathrm{X}_{5}\right)+\left(\mathrm{X}_{4}+\mathrm{X}_{5}+\mathrm{X}_{14}\right)+\left(\mathrm{X}_{15} \cdot \mathrm{X}_{16}+\mathrm{X}_{17} \cdot \mathrm{X}_{18} \cdot \mathrm{X}_{19}\right) \\
= & \left(\mathrm{X}_{1}+\mathrm{C}_{1} \cdot \mathrm{X}_{6}+\mathrm{X}_{10} \cdot \mathrm{X}_{11}+\mathrm{C}_{2} \cdot \mathrm{X}_{7}\right)+\mathrm{X}_{2}+\mathrm{X}_{3}+\mathrm{X}_{4} \cdot \mathrm{X}_{5}+\mathrm{X}_{4}+\mathrm{X}_{5}+\mathrm{X}_{14}+\mathrm{X}_{15} \cdot \mathrm{X}_{16}+\mathrm{X}_{17} \cdot \mathrm{X}_{18} \cdot \mathrm{X}_{19} \\
& =\mathrm{X}_{1}+\left(\mathrm{X}_{7}+\mathrm{X}_{8}+\mathrm{X}_{9}\right) \cdot \mathrm{X}_{6}+\mathrm{X}_{10} \cdot \mathrm{X}_{11}+\mathrm{X}_{7} \cdot \mathrm{X}_{12} \cdot \mathrm{X}_{13}+\mathrm{X}_{2}+\mathrm{X}_{3}+\mathrm{X}_{4}+\mathrm{X}_{5}+\mathrm{X}_{14}+\mathrm{X}_{15} \cdot \mathrm{X}_{16}+\mathrm{X}_{17} \cdot \mathrm{X}_{18} \cdot \mathrm{X}_{19} \\
& =\mathrm{X}_{1}+\mathrm{X}_{2}+\mathrm{X}_{3}+\mathrm{X}_{4}+\mathrm{X}_{5}+\mathrm{X}_{14}+\mathrm{X}_{6} \cdot \mathrm{X}_{7}+\mathrm{X}_{6} \cdot \mathrm{X}_{8}+\mathrm{X}_{6} \cdot \mathrm{X}_{9}+\mathrm{X}_{10} \cdot \mathrm{X}_{11}+\mathrm{X}_{7} \cdot \mathrm{X}_{12} \cdot \mathrm{X}_{13}+\mathrm{X}_{15} \cdot \mathrm{X}_{16}+\mathrm{X}_{17} \cdot \mathrm{X}_{18} \cdot \mathrm{X}_{19}
\end{aligned}
$$

The accident tree has 13 minimum cut sets, respectively

$\mathrm{K} 1=\{\mathrm{X} 1\}, \mathrm{K} 2=\{\mathrm{X} 2\}, \mathrm{K} 3=\{\mathrm{X} 3\}, \mathrm{K} 4=\{\mathrm{X} 4\}, \mathrm{K} 5=\{\mathrm{X} 5\}, \mathrm{K} 6=\{\mathrm{X} 14\}, \mathrm{K} 7=\{\mathrm{X} 6, \mathrm{X} 7\}$, $\mathrm{K} 8=\{\mathrm{X} 6, \mathrm{X} 8\}, \mathrm{K} 9=\{\mathrm{X} 6, \mathrm{X} 9\}, \mathrm{K} 10=\{\mathrm{X} 10, \mathrm{X} 11\}, \mathrm{K} 11=\{\mathrm{X} 7, \mathrm{X} 12, \mathrm{X} 13\}, \mathrm{K} 12=\{\mathrm{X} 15, \mathrm{X} 16\}$, $\mathrm{K} 13=\{\mathrm{X} 17, \mathrm{X} 18, \mathrm{X} 19\}$ 


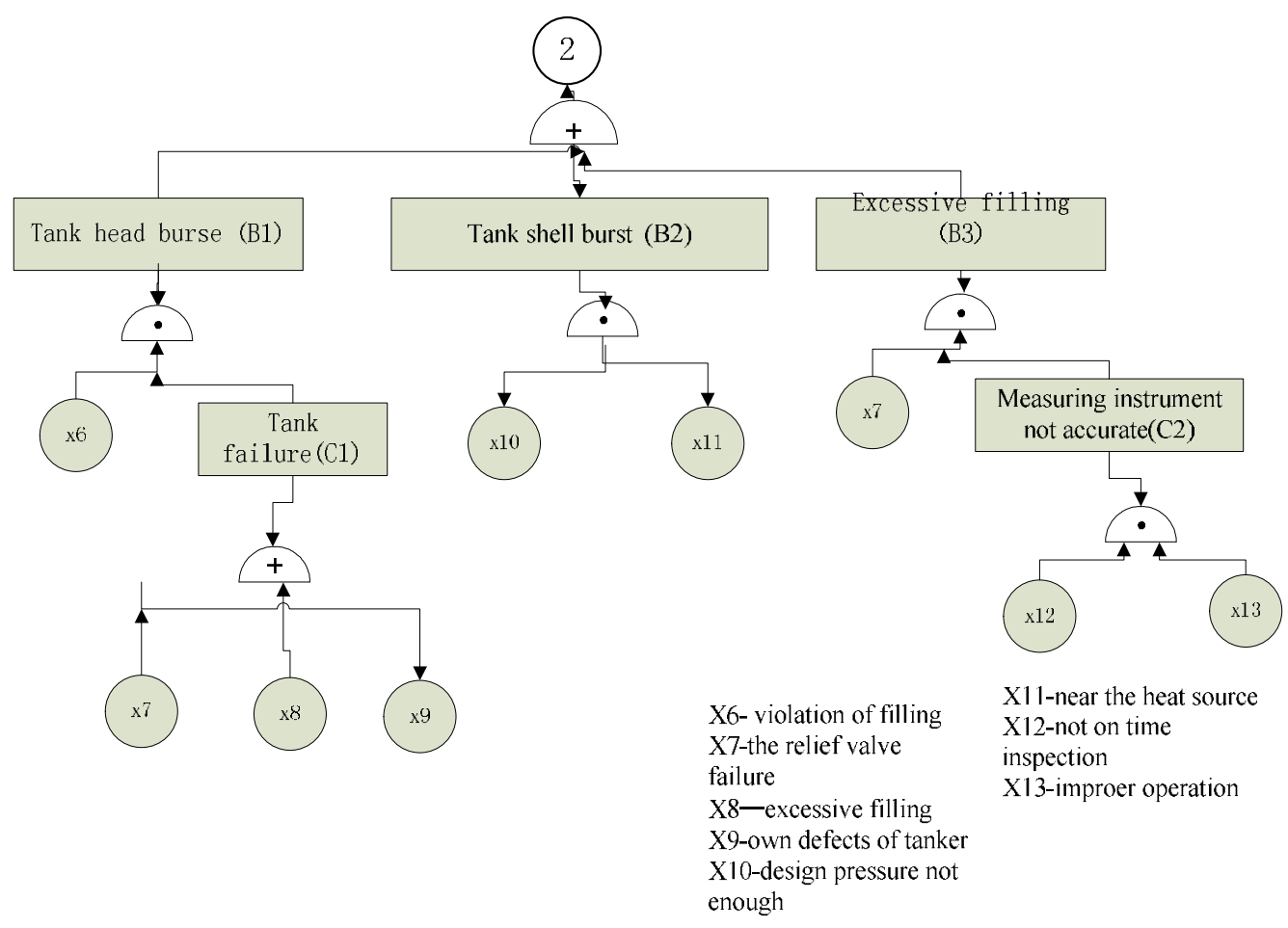

Figure 3-2 liquid ammonia tank road transportation accident tree diagram B

\section{Structure Importance}

Analysis of the structure importance of each basic event can learn of the influence degree of the top event to each basic event happened. The structure importance of each basic event of the above example can use the minimum cut sets to analysis. 13 minimum cut set of accident tree, K1 to $\mathrm{K} 6$ are single event of minimum cut sets, the other seven basic event of minimum cut sets are two or more events, if in accordance with the basic event of minimum cut sets, the basic events of less cut set of basic event structure important coefficient than basic event of the cut set of basic events big principles, $\mathrm{I} 1=\mathrm{I} 2=\mathrm{I} 3=\mathrm{I} 2=\mathrm{I} 5=\mathrm{I} 14$ and to the maximum.

$\mathrm{K} 7, \mathrm{~K} 8, \mathrm{~K} 9, \mathrm{k} 10 / 19$ dated, $\mathrm{K} 12$, the five basic event of minimum cut sets are equal in number, for both, only the X6 appeared three times, and other basic events were appears only once; K11, K13 number are three basic events, and occurrences are for once, according to appear only in the basic event number equal to a number of minimum cut set important coefficient in accordance with the occurrences of each basic event structure, namely appear less frequently, the structure importance coefficient of small, occurrences, and more important factor in its structure; Occurrences are equal, the principle of equal important factor in its structure, combining the principle of single event, we can get

$$
\mathrm{I} 6>\mathrm{I} 7>\mathrm{I} 8=\mathrm{I} 9=\mathrm{I} 10=\mathrm{I} 11=\mathrm{I} 15=\mathrm{I} 16>\mathrm{I} 12=\mathrm{I} 13=\mathrm{I} 17=\mathrm{I} 18=\mathrm{I} 19 .
$$

From the above analysis, the fault tree structure of basic event importance sorting as follows:

$$
\mathrm{I} 1, \mathrm{I} 2=\mathrm{I} 3=\mathrm{I} 2=\mathrm{I} 5=\mathrm{I} 14>\mathrm{I} 6>\mathrm{I} 7>\mathrm{I} 8=\mathrm{I} 9=\mathrm{I} 10=\mathrm{I} 11=\mathrm{I} 15=\mathrm{I} 16>\mathrm{I} 12=\mathrm{I} 13=\mathrm{I} 17=\mathrm{I} 18=
$$

\subsubsection{Probability Calculation of Liquid Ammonia Tank Car Road Transportation Accident}

The calculation of the probability of top event on the basis of minimum cut sets:

$\mathrm{g}=1-(1-\mathrm{qk} 1) \cdot(1-\mathrm{qk} 2) \cdot(1-\mathrm{qk} 3) \cdot(1-\mathrm{qk} 4) \cdot(1-\mathrm{qk} 5) \cdot(1-\mathrm{qk} 6) \cdot(1$

$-\mathrm{qk} 7) \cdot(1-\mathrm{qk} 8) \cdot(1-\mathrm{qk} 9) \cdot(1-\mathrm{qk} 10) \cdot(1-\mathrm{qk} 11) \cdot(1-\mathrm{qk} 12) \cdot(1-\mathrm{qk} 13)$

$$
=1-(1-\mathrm{q} 1) \cdot(1-\mathrm{q} 2) \cdot(1-\mathrm{q} 3) \cdot(1-\mathrm{q} 4) \cdot(1-\mathrm{q} 5) \cdot(1-\mathrm{q} 14) \cdot(1-
$$


$\mathrm{q} 6 \mathrm{q} 7) \cdot(1-\mathrm{q} 6 \mathrm{q} 8) \cdot(1-\mathrm{q} 6 \mathrm{q} 9) \cdot(1-\mathrm{q} 10 \mathrm{q} 11) \cdot(1-\mathrm{q} 7 \mathrm{q} 12 \mathrm{q} 13) \cdot(1-\mathrm{q} 15 \mathrm{q} 16) \cdot(1-$ q17q18q19)

\section{Case Summary}

In the basic event structure important degree from fault tree we can see that vehicles valve failure, vehicle turning speed too fast, mechanical failures, bad weather, the improper operation and speeding such six events put in the first place, which illustrates the six events the main reason for the liquid ammonia tank car road transportation accident; The second is illegal canned; The relief valve failure in third; Fourth is the six events such as excessive and tank filling defect, design pressure, tank away from heat, hot weather, tires on fire; The last is non-inspection, wrong operation, the filling improper loading, poor quality of the storage, the management confusion of tank and pressure vessel this five events, are the most secondary reason of liquid ammonia tank car road transport accidents.

Liquid ammonia tank car road transportation accidents mainly include a cartwheel, liquid ammonia tank leakage, impact collision, bums and several aspects, so the prevention of the accident can take measures from these aspects. Analysis of accident tree can make us learn about the number of causality and illustrate the accident probability.

Basic cause of the accident has 19,9 of which related to the equipment, therefore in the liquid ammonia tank car transport accidents, safety protection measures of the equipment is very important, at the same time, regulators to pay close attention to the operation of the staff.

To consider from the angle of the people, we should strengthen the safety awareness of staff and skills training.

\section{Liquid Ammonia Tank Car Road Transport Safety Management Countermeasures Based on FTA}

Through the analysis of the case of liquid ammonia road transportation accident in this paper we know that cartwheel, liquid ammonia tank leakage, impact crash and combustion is given priority, the basic cause of the accident has 19. According to these reasons, we put forward the following safety management countermeasures about the liquid ammonia tank car road transport.

\section{As to Vehicle Failure and the Bad Weather}

To conduct a comprehensive inspection on a regular basis for liquid ammonia transport vehicles, found that aging or failure of transportation vehicles, immediately to replace or repair. Enterprise should do regular inspection of vehicles and cannot ignore aging or failure of transport vehicles, whose consequences of doing so often make hidden hazards. Conveyancer should improve this aspect of consciousness, in accordance with the company's instructions, actively cooperate with the company's inspection.

Before transportation we should check the weather, do not do any transport activities under the bad weather, especially in hot weather. Hot, dry weather is easy to cause the spontaneous combustion or explosion of liquid ammonia tank; If transportation activities must be conducted, it shall be well adopted safety protective measures, or carried out in the night of the liquid ammonia tank car transportation activities; Liquid ammonia tank must be installed with fire equipment such as safety protective equipment; When the liquid ammonia tank car drivers drive they should pay attention to the road conditions, avoid the liquid ammonia tank car accident due to poor road conditions. Not in bad weather, especially under the high temperature weather transportation activities is a requirement of liquid ammonia transport safety for the sake of personal safety and property security, we should comply with these requirements. If the goods is urgent to transportation, we should prepare enough cold water in the heat transport, also should carefully 
check whether the vehicle in good condition before travel equipped with fire extinguishing equipment. Fortunately, because of the importance and risk of liquid ammonia, many enterprises now pay more attention to the security problems in the process of liquid ammonia transport, they also realize that bad weather would cause damage and loss, which makes them try to reduce transport activity in bad weather.

\section{As to Staff Management and Technical Training}

Strengthen the management of liquid ammonia tank car driver training, especially the security awareness training, operation technology and laws and regulations; Strengthen the liquid ammonia tank car escort personnel for the supervision of the driver's driving behavior; Physical examination and psychological examination on a regular basis to the driver to ensure their physical and mental health to avoid the health impact on the traffic safety. Now many enterprises will held some liquid ammonia transport safety training irregularly, and let more drivers to attend the training, also give them more popularize knowledge of liquid ammonia transport safety management at ordinary times to gradually change their minds.

To strengthen the liquid ammonia filling personnel' legal knowledge and operating technical training; Formulate rewards and punishment system improving the vigilance of the filling operation personnel, strictly filling operation personnel shall not violate compasses operation, punish those violate compasses operation personnel, do well rewarded. Enterprise should improve the system also refer to some of the government transportation security law to gradually form a mature system, which is beneficial to ensure the safety of liquid ammonia transport, also good for personnel security, reduce the losses of the enterprise. Senior staff in the company and external professional experts can also give employees training in class to improve employees' skills, expand the knowledge of employees, and reduce hidden trouble from filling the liquid ammonia transport. System of rewards and punishments must be fair and open and let staff understood.

\section{As to Equipment and Instrument}

Strictly controlled the purchase of equipment of liquid ammonia tank car in strict accordance with the relevant national standards for liquid ammonia tank car equipment; Regular conduct a comprehensive inspection of the relief valve and other parts of the tanks, if found problems please solve immediately; To strengthen the supervision and management of liquid ammonia filling personnel, cannot let the excess liquid ammonia tank filling; Can't let filled with liquid ammonia tanks near the heat source. Enterprise who purchases the products must strictly abide by the relevant provisions of the state, purchase qualified products, which is not only responsible for themselves but also responsible to society. If we do not strengthen the inspection of products and the supervision of the operator, it not only brings life safety threat, enterprise will lost property and bear legal responsibility.

Inspection on time to instrument of the measurement of the tank to ensure accuracy; To classify management for pressure vessel avoiding the happening of pressure vessel chaotic using situation. Enterprise timely inspection on measuring instrument is to ensure its accuracy, which could greatly reduce risks because of the instrument overfilling the perils and reduce the risk of liquid ammonia transport from its source. Classifying management for pressure vessel, chaos will not easily happen during the use of the container, also to eliminate hidden dangers from the source.

\section{Conclusion}

Since liquid ammonia tank car road transportation accident reasons are diverse, this paper listed the cause of the accident just based on the analysis of some accident cases in nearly a decade on the base of FTA, which doesn't mean all of them. A lot of the causes of liquid ammonia tank car 
road transportation accident we have not listed to analysis and research. we need more comprehensive and deeply study on the liquid ammonia tank car road transport in further research.

\section{Acknowledgement}

This research was supported by Key Discipline for Logistics Management Major of Shanghai Polytechnic University(A20NH1609B21-61) and Training of Young Teachers' Scientific Research Project for 2015(B50YC150005P4) .

\section{Reference}

[1] Lai Yongcai. Road transport of liquid dangerous goods safety analysis [J]. China Survey, 2015 (5) : 101-103.

[2] Zhou Yuxi etc. Liquid ammonia tank leakage accident simulation analysis with the quantitative risk assessment $[\mathrm{J}]$. Journal of Chongqing University (natural science edition), 2015, 32 (12) : 87-93.

[3] Chao-hua Li, etc. Based on March 1 big tanker transport of dangerous goods regulation research [J]. Journal of Transportation Enterprise Management, 2015, 30 (5) : 63-64.

[4] Ms Cheung. The low temperature tanker spill treatment [J]. China's Emergency rescue, 2015 (2) : 40-44.

[5] Zao Ming. The safe usage of ammonia (J) Security, 2013 (9) : 26-27.

[6] Xuan. The ministry of public security bureau issued an emergency notice requirements strengthen liquid dangerous goods vehicles around the installation and use of emergency switching-off device management [J]. Journal of Automotive and Security, 2015 (2) : 19.

[7] Xiao-juan Wang, etc. The liquid ammonia tank leakage under different storage environment risk comparison [J]. Guangdong Chemical Industry, 2015 (10) : 61-62.

[8] Chen Han. For road transportation accident emergency rescue research [D]. Beijing: the capital university of economics and trade. 2015.

[9] Yang Yue. Liquid ammonia leaked the environmental risk assessment and risk management measures study [J]. Journal of Resource Saving and environmental protection, 2015 (6).

[10] Wei Donghui Wei Xuezhen. Liquid ammonia loading and unloading process of accident analysis [J]. Journal of China national Machinery, 2015 (7) : 149-150.

[11] Dream of, etc. High ammonia decomposition device of liquid ammonia tank fire explosion hazard analysis [J]. Journal of Safety Science and Technology of China, 2014 (8) : 150-155.

[12] Mr. Wang. A tanker of railway dangerous goods transportation safety technology research [D]. Lanzhou: Lanzhou Jiaotong University, 2014.

[13]Ya-jing He. Road transport of dangerous goods safety management countermeasures study [D]. $\mathrm{Xi}$ 'an: Chang 'an University. 2014.

[14] Dao-yuan Wang. On the storage and transportation of the liquid ammonia [J]. Journal of China Petroleum and Chemical Industry Standard and Quality, 2014 (8) : 22.

[15] Jiang Dajun. Discuss how to do a good job of dangerous goods transportation management [J]. Journal of Information Science andTechnology, 2014 (36) : 120. 